\title{
EXPOSURE TO CULTURABLE AND TOTAL MICROBIOTA IN CULTURAL HERITAGE CONSERVATION LABORATORIES
}

\author{
RAFAŁ L. GÓRNY ${ }^{1}$, ALEKSANDER S. HARKAWY², ANNA ŁAWNICZEK-WAŁCZYK ${ }^{1}$, \\ JOANNA KARBOWSKA-BERENT ${ }^{3}$, AGNIESZKA WLAZŁO ${ }^{4}$, ANNA NIESLER ${ }^{4}$, \\ MAŁGORZATA GOŁOFIT-SZYMCZAK ${ }^{1}$, and MARCIN CYPROWSKI ${ }^{1}$
}

${ }^{1}$ Central Institute for Labour Protection - National Research Institute, Warszawa, Poland

Laboratory of Biohazards, Department of Chemical, Aerosol and Biological Hazards

${ }^{2}$ Jan Długosz University, Częstochowa, Poland

Institute of Fine Arts

${ }^{3}$ Nicolaus Copernicus University, Torun, Poland

Institute for the Study, Restoration and Conservation of Cultural Heritage

${ }^{4}$ Institute of Occupational Medicine and Environmental Health, Sosnowiec, Poland

Department of Biohazards and Immunoallergology

\begin{abstract}
Objectives: To date, the scientific source materials usually focus on microbial contamination of the museum or library collections themselves, while the exposure of persons who professionally deal with this type of objects in cultural heritage conservation laboratories is ignored. Material and Methods: The study was carried out in 9 naturally ventilated conservation laboratories with no history of water damage. Viable (understood as culturable) bioaerosol stationary samples were collected in both outdoor and indoor environments using 6-stage Andersen impactor. Simultaneously, stationary and personal indoor bioaerosol measurements were carried out using both Gesamtstaubprobenahme an der Person (GSP) and Button filter samplers. These measurements were complemented by evaluation of microbial content in the dust settled on conserved works of art. All impactor, filter, and settled dust samples were quantitatively examined to obtain viable and total concentrations of bacteria and fungi. All isolated microbial strains were taxonomically identified. Results: At workplaces, the concentrations of viable microorganisms in air were below $2000 \mathrm{cfu} / \mathrm{m}^{3}$ and accounted for not more than $5.5 \%$ of total microbiota. The study showed that quantitative assessment of viable bioaerosol can be made with an Andersen impactor as well as by using Button and GSP filter samplers, irrespective of whether they are applied for personal or stationary measurements. Compared to the impactor, however, the use of filter samplers for microbial contamination monitoring substantially limits the scope of qualitative information which can be obtained. Size distribution analysis revealed that the largest "load" of microorganisms can penetrate into the respiratory tract between the trachea and terminal bronchi, and thereby may be responsible for allergic inflammations in exposed workers. Conclusions: The precise assessment of microbial hazards in conservation laboratories should comprise control of both viable and total particle counts. The hermetization of such workplaces and control of relative humidity should be implemented and maintained to assure proper hygienic conditions.
\end{abstract}

Key words:

Settled dust, Bioaerosol, Conservation laboratory, Cultural heritage, Occupational exposure, Microbial hazards

This study was supported by the Multiannual Programme "Improvement of safety and working conditions 2011-2013" funded by the Polish Ministry of Labour and Social Policy (Grant No. 04.A.12). Grant manager: Prof. Rafał L. Górny, Ph.D., D.Sc.

Received: March 11, 2015. Accepted: May 9, 2015.

Corresponding author: R.L. Górny, Central Institute for Labour Protection - National Research Institute, Laboratory of Biohazards, Department of Chemical, Aerosol and Biological Hazards, Czerniakowska 16, 00-701 Warszawa, Poland (e-mail: ragor@ciop.pl). 


\section{INTRODUCTION}

Pursuant to the Convention adopted by the General Conference of the United Nations Educational, Scientific and Cultural Organization, it is necessary to develop an effective system of collective protection of the cultural and natural heritage of unique common value in order to ensure that it is identified, secured, conserved and restored [1]. Various types of museums, libraries and archives are the institutions that constitute the key elements of this system. To perform their tasks, most of them are obliged to have, and the remaining ones to cooperate with, conservation laboratories, which are responsible for good condition of the exhibits.

Depending on the size of a given facility, between several and a few dozen workers are employed in conservation laboratories. Due to dust and microbial contamination, as well as evidence of adverse health outcomes among employees, systematic control of the quality of air and surfaces in the laboratories where museum exhibits are conserved and restored should become an integral part of hygiene monitoring procedures in this specific indoor environment.

Harmful microbiological agents in the work environment are usually in the form of bioaerosols [2] comprising viable and non-viable microorganisms as well as the structures and substances produced by those microorganisms. Microbes can be found in the atmospheres of the conservation laboratories alone or in aggregates with dust particles, fibers, or liquid droplets. Those structures penetrate into the employee's body through the respiratory tract, and the effects of their activity are to a major extent dependent on their ability to deposit within the body [3].

Despite the risks, to date, the literature on the subject lacks a comprehensive analysis of the issue of contamination with harmful biological agents at cultural heritage conservation laboratories. The scientific source materials usually focus on microbial contamination of the museum or library collections themselves, while the exposure of professionals handling those objects is ignored [e.g., 4-6]. This can lead to errors in the system of employees' health protection and substantial mismanagement of work safety [7].

The aim of this study was to assess microbial contamination of the work environment in conservation laboratories. In particular, the aim was to determine:

- to what degree the workplaces at conservation laboratories are contaminated with harmful bacterial and fungal agents,

- to what degree conservation works affect the level of microbial contamination,

- whether or not and, if affirmative, to what degree the material from which the conserved collections are made and the level of microbial contamination affect the hygienic quality of the air in the studied indoor spaces,

- whether or not and, if affirmative, to what degree the microbial contamination of the ambient air contributes to the overall contamination level of the work environment in question.

In addition, for better quantification and control of the risk connected with exposure to harmful microbiological agents in workplaces, the following were assessed:

- utility of 2 commonly applied measurement techniques (i.e., impaction and filtration) for estimation of exposure to biological aerosols;

- utility of 2 high-efficiency filtration samplers for stationary and personal measurements of bacterial and fungal aerosols;

- the extent of exposure to bioaerosols, when it is estimated from results of conventional measurement of concentration of viable particles, and when the measurement of concentration of all particles, i.e., both viable and non-viable (known as total bioaerosol measurement), is allowed for;

- utility of information about particle size distribution of bioaerosols for predictive assessment of health hazard 
connected with exposure to harmful microbiological agents in conservation laboratories.

\section{MATERIAL AND METHODS}

The study was carried out in 9 cultural heritage conservation laboratories located in 6 towns across Poland. It included independent laboratories and laboratories located in museums, libraries and archives, where conservation works on old prints, documents, easel paintings, sculptures and handicrafts (including utility objects made of natural materials, i.e., wood and leather) were performed. All measurements were made in naturally ventilated rooms. No history of water damage of the building envelopes or visible mold growth on their surfaces were observed.

Bioaerosol measurements were carried out in laboratories during working hours (e.g., during conservation of objects, inspection of collections, cleaning of exhibits, etc.) and in rooms directly adjacent to the laboratories where no conservation work was carried out (in order to determine the indoor background level of contamination). Concomitantly, bioaerosol measurements were made in the immediate vicinity of the building (in the ambient air) in order to determine the outdoor background level of contamination and the degree to which microorganisms migrated to the studied interiors.

The measurements were carried out from spring to autumn when the average outdoor air temperature was higher than $10^{\circ} \mathrm{C}$ for at least 7 consecutive days. Viable (understood in this study as culturable) bioaerosol stationary samples were simultaneously collected in both outdoor and indoor environments using a 6-stage Andersen impactor (model 10-710, prod. Andersen Instruments, USA) at a flow rate of $28.3 \mathrm{l} / \mathrm{min}$. At the beginning of each measurement cycle, bacterial aerosol was collected on blood trypticase soy agar (TSA) with 5\% sheep blood (Becton, Dickinson \& Co., USA) and, after impactor reloading, fungi were aspirated on malt extract agar (MEA) (Oxoid Ltd., UK). The sampling time was 5 min for both bacterial and fungal aerosols, and their concentrations were expressed in terms of the number of colony forming units in $1 \mathrm{~m}^{3}$ of sampled air $\left(\mathrm{cfu} / \mathrm{m}^{3}\right)$.

Simultaneously with the impactor measurements, stationary and personal bioaerosol samples were collected in the conservation laboratories using both Gesamtstaubprobenahme an der Person (GSP) (Ströhlein GmbH \& Co., Germany) [8,9] and Button (SKC Ltd., USA) [9-14] aerosol samplers equipped with pumps (model 224PCTX8; SKC Ltd., USA). During stationary bioaerosol measurements, all 3 samplers (Andersen, GSP, and Button) were placed at a height of $1.5 \mathrm{~m}$ above floor level (height of seated worker) and at a distance of $1 \mathrm{~m}$ from each other to avoid possible interferences between them. The personal samples were collected at a flow rate of $41 / \mathrm{min}$ for $30 \mathrm{~min}$ using both filter samplers clipped to special shoulder straps on an analyst's laboratory coat, and loaded with gelatin filters (Sartorius AG, Germany) with a pore size of $3 \mu \mathrm{m}$ and diameters of $37 \mathrm{~mm}$ and $25 \mathrm{~mm}$, respectively.

After sampling, each filter was removed from its holder and dissolved in sterile water containing $0.01 \%$ Tween 80 . A portion of the suspension was plated on the microbiological media (the same as for bioaerosol sampling) and used for determination of culturable microorganisms $\left(\mathrm{cfu} / \mathrm{m}^{3}\right)$. The remaining portion of the suspension was used for examination of total microbial counts by a modification of the collection of airborne microorganisms on nucleopore filters, estimation and analysis (CAMNEA) method $[15,16]$.

Briefly, the resultant samples were treated with formaldehyde (37\%) (POCH SA, Poland) and then stained with acridine orange (Sigma-Aldrich Chemie GmbH, Germany). After filtration of the suspension through a black polycarbonate filter with a pore size of $0.8 \mu \mathrm{m}$ (Whatman, UK), all microorganisms were counted using an epifluorescence microscope (model Eclipse E200; Nikon, Japan) at the wavelength of $490 \mathrm{~nm}$ and their concentration was expressed as counts $/ \mathrm{m}^{3}$. 
The bioaerosol measurements were complemented by evaluation of bacterial and fungal content in the dust settled on conserved works of art. Each time, the dust was collected using sterile cotton swabs (HAGMED, Poland) from the surface of $100 \mathrm{~cm}^{2}$ (a square shaped $10 \times 10 \mathrm{~cm}$ sterile template was applied). After sampling, to extract the collected microorganisms, the cotton swabs were vortexed for $10 \mathrm{~min}$ using a programmable rotator-mixer (model Multi RS-60; Biosan, Latvia) in $5 \mathrm{ml}$ distilled water. The spread plate method was applied, where $0.2 \mathrm{ml}$ of the resulting suspension was spread evenly over the same media as used for bioaerosol sampling.

All impactor, filter, and settled dust samples were incubated at the temperature of: bacteria -1 day at $37^{\circ} \mathrm{C}$, followed by 3 days at $22^{\circ} \mathrm{C}$ and 3 days at $4^{\circ} \mathrm{C}$; fungi -4 days at $30^{\circ} \mathrm{C}$ followed by 4 days at $22^{\circ} \mathrm{C}$. After incubation, the viable microbial concentrations in the air and dust were calculated as colony forming units per $1 \mathrm{~m}^{3}\left(\mathrm{cfu} / \mathrm{m}^{3}\right)$ and per $100 \mathrm{~cm}^{2}\left(\mathrm{cfu} / 100 \mathrm{~cm}^{2}\right)$, respectively. Bacterial and yeast strains were identified by Gram staining (111885 Gramcolor stain set; Merck KGaA, Germany) [17], by determination of their morphology and, finally, by the biochemical analytical profile index (API) tests (BioMérieux, France). Filamentous fungi were identified according to their morphology using several identification keys [18-22]. During the sampling of the biological aerosols, the air temperature and relative humidity, as major microclimate parameters influencing the growth of the studied microbiota, were measured using a hytherograph (model Omniport 20; E+E Elektronik GmbH, Austria).

All bioaerosol, settled dust, and microclimate parameter measurements were performed in triplicate. The collected data were statistically processed using analysis of variance (ANOVA) followed by Scheffe's test, t-test and correlation analysis using Statistica (data analysis software system) version 10 (StatSoft, Inc., USA).

\section{RESULTS}

\section{Quantitative analysis of bacterial}

\section{and fungal microbiota in air samples}

Concentrations of bacterial and fungal aerosols measured using an Andersen impactor in the outdoor background, indoor background and at workplaces in conservation laboratories are presented in Table 1. Although they did not exceed the value of $2000 \mathrm{cfu} / \mathrm{m}^{3}$ in any segment of the studied environments, statistically significant differences were found between them (ANOVA: $p<0.05$ ). The lowest concentrations of the studied bioaerosols were found in the indoor air and the highest at workplaces. The differences were particularly evident for bacterial aerosol (Scheffe's test: $\mathrm{p}<0.05$ ).

Figure 1 presents the results of concentration measurements of viable (which are understood as those able to form colonies on an appropriate microbiological medium)

Table 1. Concentrations of microorganisms measured using Andersen impactor at workplaces in conservation laboratories and in indoor and outdoor backgrounds

\begin{tabular}{|c|c|c|c|c|}
\hline \multirow{3}{*}{ Sampling place } & \multicolumn{4}{|c|}{$\begin{array}{c}\text { Concentration } \\
{\left[\mathrm{cfu} / \mathrm{m}^{3}\right]}\end{array}$} \\
\hline & \multicolumn{2}{|c|}{ bacteria } & \multicolumn{2}{|c|}{ fungi } \\
\hline & $\mathrm{M}$ & $\min .-\max$ & $\mathrm{M}$ & $\min .-\max$ \\
\hline Workplaces & 570 & $105-1845$ & 201 & $49-413$ \\
\hline Indoor background & 74 & 21-119 & 17 & $0-42$ \\
\hline Outdoor background & 334 & $211-487$ & 563 & $56-1222$ \\
\hline
\end{tabular}

M - mean; min. - minimal value; max - maximal value. 


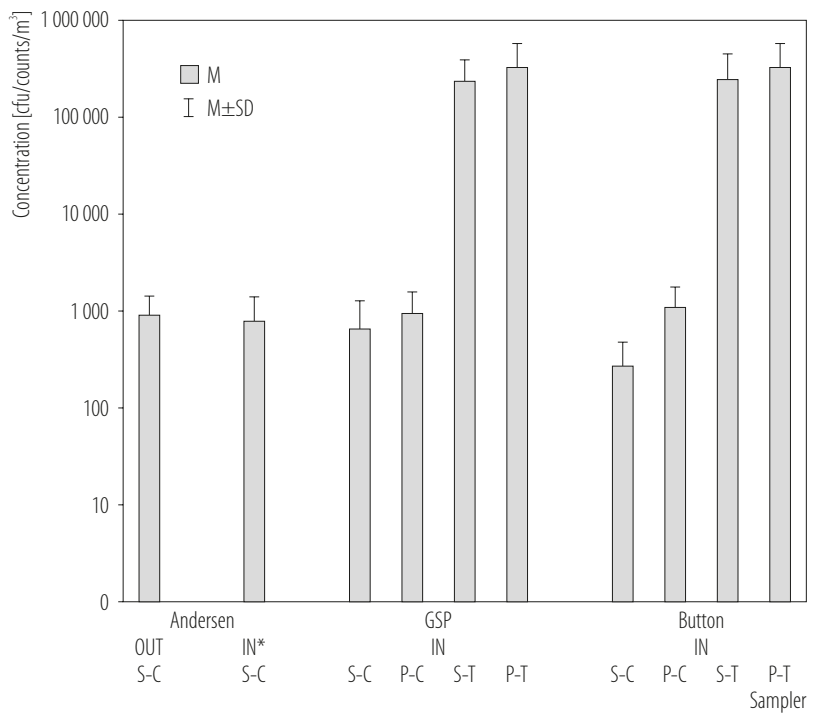

M - mean; SD - standard deviation; OUT - outdoor environment; IN - indoor environment (workplaces); $\mathrm{S}$ - stationary sampling; $\mathrm{P}$ - personal sampling; $\mathrm{C}$ - culturable count; $\mathrm{T}$ - total count. The data are given as mean values and standard deviations of 18 or 36 (marked with *) repeats.

Fig. 1. Concentrations of microorganisms in indoor and outdoor air at cultural heritage conservation laboratories measured using Andersen, GSP and Button samplers

and total microorganisms (understood as the total of microorganisms, i.e., able and unable to form colonies on appropriate microbiological medium as well as non-viable) in the ambient (outdoor) air and at workplaces in conservation laboratories, obtained through stationary and personal measurements. Analysis of viable bioaerosol particle concentrations, irrespective of whether they were obtained by stationary (Andersen stationary vs. Button stationary vs. GSP stationary) or personal measurements (Andersen stationary vs. Button personal vs. GSP personal), did not show statistically significant differences between the 3 samplers (ANOVA: $p>0.05$ in both cases). At the same time, statistically significant differences were observed when total microbial concentrations measured with Button and GSP samplers, used both for stationary and personal measurements, were compared with concentrations of viable microorganisms determined by stationary measurements with the Andersen impactor (Andersen stationary/viable vs. Button stationary/ total vs. GSP stationary/total and Andersen stationary/ viable vs. Button personal/total vs. GSP personal/total) (ANOVA: in both cases $\mathrm{p}<0.001$ ).

At workplaces in conservation laboratories, total concentrations of bioaerosol determined using Button and GSP samplers, for both stationary and personal measurements, were always significantly higher than those obtained using the Andersen impactor (Scheffe's test: in all 4 cases $p<0.01$ ). Moreover, the viable bioaerosol concentrations were always significantly lower than total airborne microorganism concentrations, both in the case of Button and GSP sampler measurements; and in both cases, irrespective of whether or not it was a stationary or personal sampling (Student's t-test results: Button sampler - stationary $\mathrm{p}<0.01$, personal $\mathrm{p}<0.05$; GSP sampler - stationary $\mathrm{p}<0.05$, personal $\mathrm{p}<0.05$, respectively).

Such results explicitly show that viable bioaerosol particles constituted a small percentage of the total concentration of microorganisms. In the presented study, the proportions were as follows: for stationary and personal measurements with Button as well as GSP samplers, viable bioaerosol constituted $0.2-0.5 \%$ and $0.1-1.5 \%$, as well as $0.1-5.5 \%$ and $0.1-3.6 \%$ of total bioaerosol, respectively. Figure 1 also presents the concentrations of viable microorganisms in the air samples concurrently collected using Button and GSP samplers, which were both stationary and personally applied. Irrespective of the sampler, the concentrations obtained by stationary measurements were always lower than personal ones. While in the case of the GSP sampler, the concentrations presented quite a wide range, which translated into insignificant statistical relationships; in the case of the Button sampler, significantly higher concentration values were obtained by personal measurements, compared with stationary measurements (Student's t-test: $\mathrm{p}<0.05$ ). 


\section{Quantitative analysis of bacteria and fungi in dust settled on cultural objects}

The concentrations of bacteria and fungi, determined through a culture-based method in settled dust samples were mean value \pm standard deviation (M \pm SD): $110 \pm 72 \mathrm{cfu} / 100 \mathrm{~cm}^{2}$ and $75 \pm 72 \mathrm{cfu} / 100 \mathrm{~cm}^{2}$, respectively. Correlation analysis between the concentrations of microorganisms in the settled dust and in the air at the studied workplaces did not show statistically significant relationships.

\section{Qualitative analysis of microbiota in air samples}

The results of the qualitative analysis of microorganisms isolated from air samples collected outdoors and in the studied conservation laboratories are collated in Figure 2 and Table 2. The percentage distribution analysis of individual groups of microorganisms in relation to total microbiota isolated from the air, showed that in both environments the most prevalent were: among bacteria - Gram-positive cocci (44\% and $67 \%$ of total airborne biota, respectively) and non-sporing Gram-positive rods (45\% and 18\%, respectively); and among fungi - molds (which accounted for $99 \%$ and $97 \%$ of mycobiota, respectively). Among bacteria, from both outdoor and indoor air samples were also isolated Gram-positive spore-forming rods and mesophilic actinomycetes, which accounted for up to $9 \%$ and $6 \%$ at most, respectively. Gram-negative rods were not identified either in the ambient or in the indoor air.

The qualitative analysis of outdoor and indoor microorganisms allowed identification, to the genus and/or species level, a total of 99 microorganisms, including 42 bacteria and 57 fungi. This microbiota comprised organisms which were highly cellulolytic (among others Chaetomium, Alternaria, Ulocladium, Fusarium, Aspergillus and Penicillium), proteolytic (among others Bacillus, Mucor, Chaetomium and Aureobasidium) and lipolytic (all the proteolytic microorganisms listed above and Paecilomyces), and hence responsible for the biodeterioration of paper, parchment, leather, paint and wood (related markings can be found in Table 2, next to the taxonomic names of the isolated microorganisms).

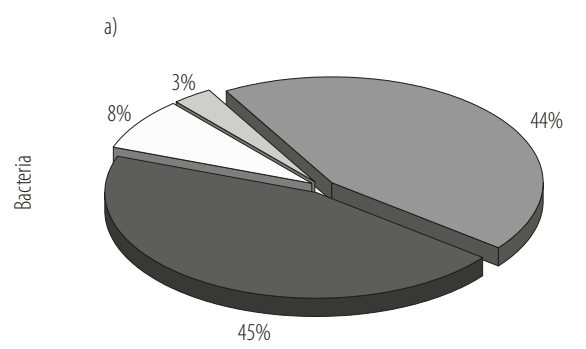

b)

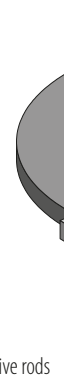

$67 \%$

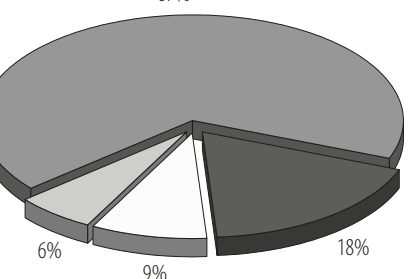

c)

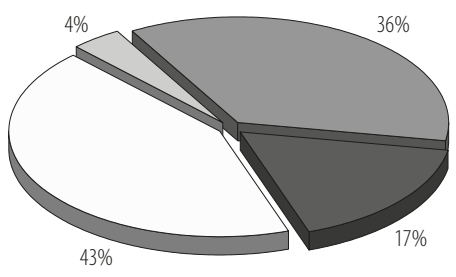
Gram-positive cocci
nonsporing Gram-positive rods
endospore forming Gram-positive rods
$\triangle$ mesophilic actinomycetes

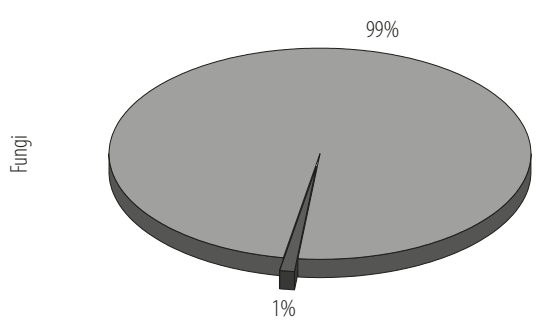

filamentous fungi

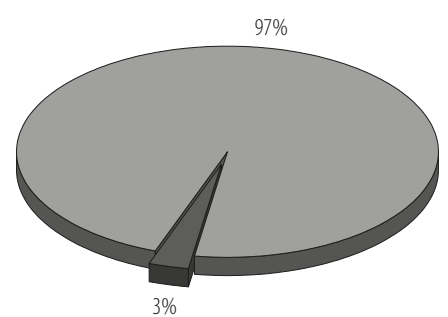

$\Delta$ yeasts

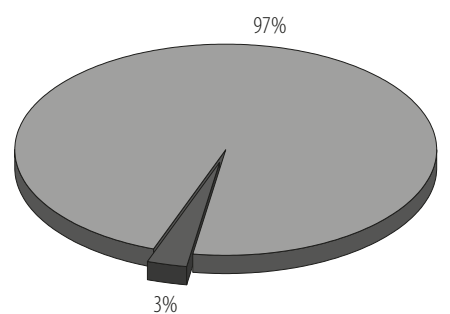

$3 \%$

Fig. 2. Bacteria and fungi isolated from the a) outdoor and b) indoor air as well as c) settled dust at cultural heritage conservation laboratories 
Table 2. Microbial taxa isolated from the air and settled dust at cultural heritage conservation laboratories

\begin{tabular}{|c|c|c|c|c|}
\hline \multirow{2}{*}{ Taxon } & \multirow{2}{*}{ Risk group $^{\mathrm{a}}$} & \multicolumn{3}{|c|}{ Sample $^{\mathrm{c}}$} \\
\hline & & outdoor air & indoor air & settled dust \\
\hline \multicolumn{5}{|l|}{ Bacteria } \\
\hline \multicolumn{5}{|l|}{ Gram-positive cocci } \\
\hline Aerococcus viridans & 1 & & + & \\
\hline Kocuria kristinae & 1 & + & + & + \\
\hline Kocuria rosea & 1 & + & $+[\#]$ & + \\
\hline Kocuria sertinia & 1 & & & + \\
\hline Kocuria varians & 1 & & + & \\
\hline Micrococcus luteus & 1 & + & {$[+][\#]$} & {$[+]$} \\
\hline Micrococcus spp. ${ }^{1,3}$ & 1 & + & + & {$[+]$} \\
\hline Staphylococcus auricularis & 1 & + & + & + \\
\hline Staphylococcus capitis & 1 & & + & \\
\hline Staphylococcus cohnii & 1 & + & $+[\#]$ & \\
\hline Staphylococcus epidermidis ${ }^{1}$ & 1 & + & + & + \\
\hline Staphylococcus haemolyticus & 1 & + & $+\#$ & {$[+]$} \\
\hline Staphylococcus hominis & 1 & + & $+\#$ & + \\
\hline Staphylococcus lentus & 1 & & + & \\
\hline Staphylococcus saprophyticus & 1 & + & + & + \\
\hline Staphylococcus sciuri ${ }^{1}$ & 1 & + & + & \\
\hline Staphylococcus warneri ${ }^{1}$ & 1 & + & + & + \\
\hline Staphylococcus xylosus & 1 & + & $+\#$ & {$[+]$} \\
\hline Staphylococcus spp. & $2^{\mathrm{b}}$ & + & {$[+][\#]$} & {$[+]$} \\
\hline \multicolumn{5}{|l|}{ nonsporing Gram-positive rods } \\
\hline Arcanobacterium haemolyticum & 1 & & & + \\
\hline Arthrobacter spp. & $2^{\mathrm{b}}$ & + & + & + \\
\hline Brevibacterium spp. ${ }^{1}$ & $2^{\mathrm{b}}$ & + & $+[\#]$ & {$[+]$} \\
\hline Cellulomonas spp. ${ }^{1}$ & 1 & & + & + \\
\hline Corynebacterium amycolatum & 1 & + & + & \\
\hline Corynebacterium auranticum & 1 & + & & \\
\hline Corynebacterium propinquum & 1 & + & + & \\
\hline Corynebacterium striatum & 1 & + & + & + \\
\hline Leifsonia aquatica & 1 & & $+\#$ & + \\
\hline Microbacterium spp. & 1 & + & $+[\#]$ & + \\
\hline Propionibacterium spp. & 1 & + & $+\#$ & + \\
\hline Rothia mucilaginosa & 1 & + & $+\#$ & + \\
\hline
\end{tabular}


Table 2. Microbial taxa isolated from the air and settled dust at cultural heritage conservation laboratories - cont.

\begin{tabular}{|c|c|c|c|c|}
\hline \multirow{2}{*}{ Taxon } & \multirow{2}{*}{ Risk group ${ }^{\mathrm{a}}$} & \multicolumn{3}{|c|}{ Sample } \\
\hline & & outdoor air & indoor air & settled dust \\
\hline \multicolumn{5}{|l|}{ Bacteria - cont. } \\
\hline \multicolumn{5}{|c|}{ endospore forming Gram-positive rods } \\
\hline Bacillus cereus ${ }^{1,3}$ & 1 & + & $+[\#]$ & {$[+]$} \\
\hline Bacillus circulans & 1 & + & $+[\#]$ & {$[+]$} \\
\hline Bacillus firmus & 1 & & + & {$[+]$} \\
\hline Bacillus licheniformis $^{1}$ & 1 & + & + & + \\
\hline Bacillus mycoides ${ }^{3}$ & 1 & + & + & + \\
\hline Bacillus pumilus ${ }^{1}$ & 1 & + & + & {$[+]$} \\
\hline Bacillus subtilis ${ }^{1}$ & 2 & & + & + \\
\hline Bacillus spp..$^{1,2,3}$ & $2^{\mathrm{b}}$ & + & $+\#$ & + \\
\hline Brevibacillus laterosporus & 1 & & & + \\
\hline Brevibacillus spp. & 1 & & + & \\
\hline Paenibacillus macerans & 1 & & $+[\#]$ & + \\
\hline \multicolumn{5}{|l|}{ mesophilic actinomycetes } \\
\hline Actinomyces spp. & 2 & & $+\#$ & + \\
\hline Nocardia spp. ${ }^{1}$ & $2^{\mathrm{b}}$ & + & $+\#$ & \\
\hline Rhodococcus spp. & $2^{\mathrm{b}}$ & + & + & + \\
\hline \multicolumn{5}{|l|}{ Fungi } \\
\hline \multicolumn{5}{|l|}{ filamentous fungi } \\
\hline Acremonium furcatum & 1 & & + & \\
\hline Acremonium strictum $^{1,3}$ & 1 & + & + & \\
\hline Acremonium spp. ${ }^{1,2}$ & 1 & {$[+]$} & {$[+][\#]$} & {$[+]$} \\
\hline Alternaria alternata ${ }^{1,3}$ & 1 & + & + & + \\
\hline Alternaria spp. ${ }^{1,2,3,4}$ & 1 & + & & + \\
\hline Aspergillus clavatus ${ }^{1}$ & 1 & + & + & \\
\hline Aspergillus flavus ${ }^{1,2,3}$ & 1 & + & & + \\
\hline Aspergillus fumigatus ${ }^{1,2,3}$ & 2 & + & + & + \\
\hline Aspergillus niger ${ }^{1,2,3}$ & 1 & + & & \\
\hline Aspergillus ochraceus ${ }^{1,2}$ & 1 & + & $+\#$ & + \\
\hline Aspergillus sydowii & 1 & + & & \\
\hline Aspergillus terreus ${ }^{1}$ & 1 & + & $+[\#]$ & {$[+]$} \\
\hline Aspergillus spp. ${ }^{1,2,3,4}$ & $2^{b}$ & + & $+[\#]$ & + \\
\hline Cephalosporium acremonium ${ }^{3}$ & 1 & + & & \\
\hline Cephalosporium charticola & 1 & + & + & \\
\hline Chaetomium funicola ${ }^{3}$ & 1 & & + & + \\
\hline
\end{tabular}


Table 2. Microbial taxa isolated from the air and settled dust at cultural heritage conservation laboratories - cont.

\begin{tabular}{|c|c|c|c|c|}
\hline \multirow{2}{*}{ Taxon } & \multirow{2}{*}{ Risk group $^{\mathrm{a}}$} & \multicolumn{3}{|c|}{ Sample $^{\mathrm{c}}$} \\
\hline & & outdoor air & indoor air & settled dust \\
\hline \multicolumn{5}{|l|}{ Fungi - cont. } \\
\hline \multicolumn{5}{|l|}{ filamentous fungi - cont. } \\
\hline Chaetomium spp. ${ }^{1,2,3,4}$ & 1 & + & + & \\
\hline Chrysonilia sitophila & 1 & + & + & \\
\hline Cladosporium cladosporioides ${ }^{1,3}$ & 1 & + & + & + \\
\hline Cladosporium sphaerospermum & 1 & + & + & + \\
\hline Cladosporium spp..$^{1,2,3,4}$ & 1 & + & & \\
\hline Epicoccum purpurescens & 1 & & + & \\
\hline Exophiala jeanselmei & 1 & & + & \\
\hline Fusarium graminearum & 1 & + & & \\
\hline Fusarium spp..$^{1,2,3,4}$ & 1 & + & $+\#$ & + \\
\hline Mucor hiemalis & 1 & & & + \\
\hline Mucor spp..$^{1,2,3}$ & 1 & + & & \\
\hline Paecilomyces carneus & 1 & + & + & \\
\hline Paecilomyces variotii ${ }^{1,2,3}$ & 1 & + & & \\
\hline Paecilomyces spp. ${ }^{1,2}$ & 1 & + & + & \\
\hline Penicillium brevicompactum ${ }^{1}$ & 1 & & + & {$[+]$} \\
\hline Penicillium chrysogenum ${ }^{1,2,3}$ & 1 & + & $+[\#]$ & {$[+]$} \\
\hline Penicillium commune $e^{1,3}$ & 1 & & $+[\#]$ & {$[+]$} \\
\hline Penicillium corylophilum ${ }^{1}$ & 1 & & & {$[+]$} \\
\hline Penicillium crustosum & 1 & & $+[\#]$ & + \\
\hline Penicillium cyclopium & 1 & & + & \\
\hline Penicillium frequentans ${ }^{1,3}$ & 1 & & + & + \\
\hline Penicillium funiculosum ${ }^{1,2}$ & 1 & + & $+[\#]$ & + \\
\hline Penicillium griseoazureum & 1 & & {$[\#]$} & {$[+]$} \\
\hline Penicillium griseofulvum & 1 & & {$[\#]$} & + \\
\hline Penicillium hirsutum & 1 & + & & \\
\hline Penicillium palitans & 1 & & $+\#$ & + \\
\hline Penicillium polonicum & 1 & + & $+\#$ & {$[+]$} \\
\hline Penicillium sublateritium & 1 & + & + & \\
\hline Penicillium verrucosum & 1 & & {$[\#]$} & {$[+]$} \\
\hline Penicillium viridicatum & 1 & + & $+\#$ & \\
\hline Penicillium spp. ${ }^{1,2,3}$ & $2^{b}$ & + & {$[+][\#]$} & {$[+]$} \\
\hline Phoma spp. ${ }^{2,3}$ & 1 & & + & \\
\hline Rhizopus oryzae ${ }^{1}$ & 1 & & $+[\#]$ & \\
\hline Rhizopus stolonifer ${ }^{1,2}$ & 1 & + & & + \\
\hline
\end{tabular}


Table 2. Microbial taxa isolated from the air and settled dust at cultural heritage conservation laboratories - cont.

\begin{tabular}{|c|c|c|c|c|}
\hline \multirow{2}{*}{ Taxon } & \multirow{2}{*}{ Risk group $^{\mathrm{a}}$} & \multicolumn{3}{|c|}{ Sample ${ }^{c}$} \\
\hline & & outdoor air & indoor air & settled dust \\
\hline \multicolumn{5}{|l|}{ Fungi - cont. } \\
\hline \multicolumn{5}{|l|}{ filamentous fungi - cont. } \\
\hline Rhizopus spp. ${ }^{1,2}$ & 1 & + & $+[\#]$ & + \\
\hline Scopulariopsis fusca & 1 & + & + & + \\
\hline Scopulariopsis spp..$^{1,2}$ & 1 & + & + & + \\
\hline Sporotrichum spp. ${ }^{1,3}$ & 1 & + & + & + \\
\hline Stachybotrys chartarum ${ }^{1,2,3}$ & 1 & & & + \\
\hline Trichoderma viride ${ }^{1,2,3}$ & 1 & & & + \\
\hline Ulocladium chartarum & 1 & + & + & + \\
\hline \multicolumn{5}{|l|}{ Yeasts } \\
\hline Candida guilliermondii & 1 & + & & + \\
\hline Candida spp. & $2^{b}$ & & & + \\
\hline Cryptococcus laurentii & 1 & & + & + \\
\hline Geotrichum candidum ${ }^{2,3}$ & 1 & + & + & {$[+]$} \\
\hline Rhodotorula mucilaginosa & 1 & + & & \\
\hline
\end{tabular}

${ }^{1}$ Paper/parchment; ${ }^{2}$ leather; $;{ }^{3}$ paint; ${ }^{4}$ wood biodeteriogens [65-69].

${ }^{a}$ Classification of biological agents according to their level of risk of infection (after Directive 2000/54/EC [23] and Ordinance of Polish Minister of Health [24]).

${ }^{b}$ Genus in which certain species are classified to the group 2 according to their level of risk of infection and allergy.

${ }^{c}$ In each environment, the species sampled using Andersen impactor (+) or filter (Button, GSP) samplers (\#) with isolation frequency higher than $50 \%$ in the groups of identified bacteria or fungi are given in squares.

Among the isolated microorganisms, Aerococcus viridans, Kocuria varians, Staphylococcus capitis, S. lentus and Brevibacillus spp. bacteria and Acremonium furcatum, Epicoccum purpurescens, Exophiala jeanselmei, Penicillium cyclopium and Phoma spp. fungi were found in the air in conservation laboratories only.

Using the classifications of harmful biological agents included in Directive 2000/54/EC [23] and Ordinance of Polish Minister of Health [24], it was ascertained that in the working environment of art conservators one can find not only microorganisms from risk group 1 (i.e., agents that are unlikely to cause human disease), but also those from risk group 2 (i.e., agents that can cause human disease and might be a hazard to workers; among others, Aspergillus fumigatus species and genera of which certain species are classified into this risk group, Staphylococcus spp., Arthrobacter spp., Brevibacterium spp., Bacillus spp., Actinomyces spp., Nocardia spp., Rhodococcus spp., Aspergillus spp., Penicillium spp. and Candida spp.). In the air and settled dust in the studied laboratories, the microorganisms (Stachybotrys chartarum, Fusarium spp., Aspergillus flavus, A. fumigatus, $A$. niger) which constitute a significant source of health hazard to workers were also identified.

\section{Qualitative analysis of bacteria and fungi in dust settled on cultural objects}

The results of qualitative analysis of microorganisms isolated from samples of settled dust, collected from the surface of objects subjected to conservation treatment in the studied laboratories, are presented in Figure 2 and 

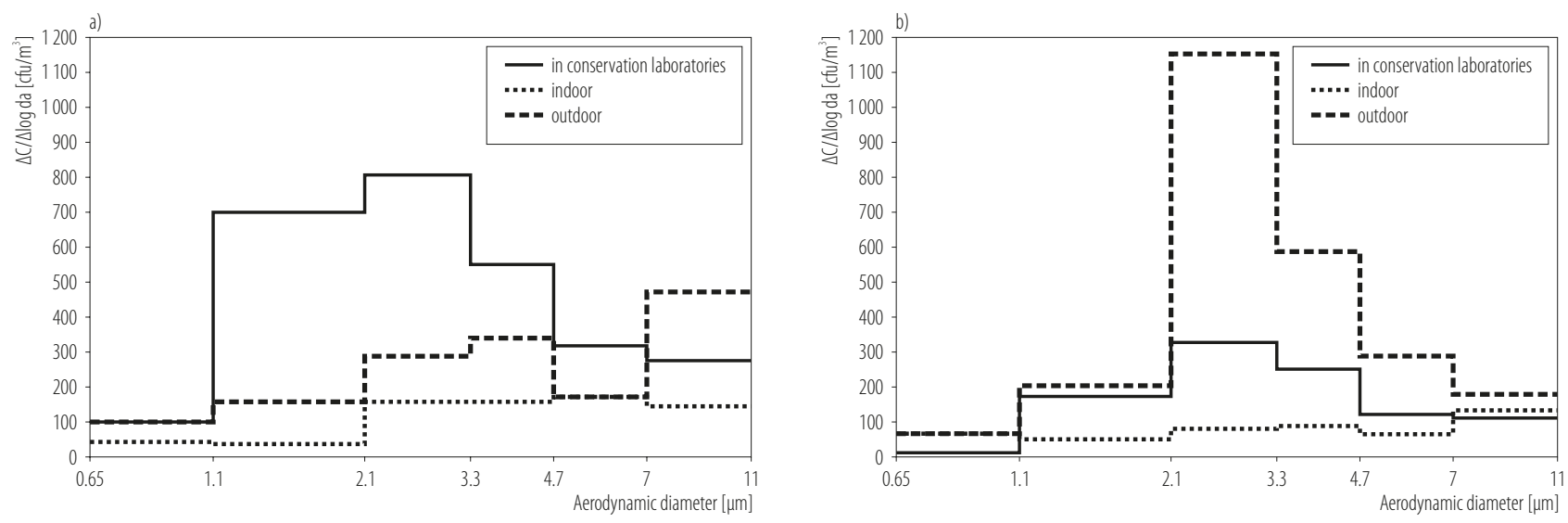

Fig. 3. Size distribution of a) bacterial and b) fungal aerosols at workplaces

Table 2. Regarding the samples of conserved objects, among bacteria Gram-positive spore-forming rods were most numerous ( $43 \%$ of total bacterial biota), followed by Gram-positive cocci (36\% of it); among fungi, molds constituted the bulk (97\%) of the mycobiota. Other groups of microorganisms were present in the settled dust in proportions similar to those detected in indoor air, i.e., non-sporing Gram-positive rods and mesophilic actinomycetes represented $17 \%$ and $4 \%$ of total bacterial biota, respectively; and yeast-like fungi constituted $3 \%$ of mycobiota.

Microbiota of the settled dust was less diverse than that of the air (as measured with Andersen impactor), although it comprised species similar to those isolated from the indoor air. In the settled dust, a total of 34 species of bacteria (from 17 genera) and 38 species of fungi (also from 17 genera) were identified. As in the case of the air, no Gram-negative rods were identified. Among isolated microorganisms, bacterial species such as Kocuria sertinia, Arcanobacterium haemolyticum and Brevibacillus laterosporus and fungi such as Mucor hiemalis, Penicillium corylophilum, Stachybotrys chartarum, Trichoderma viride and Candida spp. were present in the settled dust only.

\section{Analysis of particle size distribution}

The use of a 6-stage Andersen impactor allowed obtaining data on particle size distribution of airborne microbiota in the outdoor and indoor background, as well as at workplaces in conservation laboratories (Figure 3). Moreover, taking into account the natural sizes of bacteria and fungi from the groups predominant in the air, such analysis allowed defining the forms of studied bioaerosols, and determining the possible depth of their penetration into the human respiratory system. In the case of bacterial aerosol, significantly higher concentrations of particles were found at workplaces compared with concentrations in the indoor background and ambient air (ANOVA: $\mathrm{p}<0.05)$. This predominance was particularly evident for particles with an aerodynamic diameter of 1.1-4.7 $\mu \mathrm{m}$ when workplace and indoor background air curves were compared (Scheffe test: $p<0.05)$.

Furthermore, the drop in the number of particles formed by large $(\geq 4.7 \mu \mathrm{m})$ bacteria or bacteria and dust aggregates was characteristic for the workplace size distribution curve compared to the concentrations found in the outdoor air (Figure 3a). Due to the nature of the studied interiors, bacterial contamination (brought naturally with ambient air or unnaturally with objects requiring conservation treatment) is probably intentionally and efficiently eliminated.

The particle size distribution of fungal aerosol in the outdoor air and inside the studied interiors is presented in Figure 3b. Analysis showed that irrespective of the nature 
of the studied rooms, the strongest effect on the concentration of fungi was exerted by migrating ambient air and human activity. In the case of conservation laboratories, the additional emission of fungal aerosol particles (whose diameters ranged 1.1-4.7 $\mu \mathrm{m}$ ), measured at workplaces, exceeded the concentration found in the indoor background, but the scale of this increase did not equal the concentration of fungi in the ambient air outside such rooms (particularly with respect to diameters corresponding to aerodynamic sizes of single spores of the predominant mold species).

\section{Effects of the microclimate}

\section{on the concentration of microorganisms}

The ranges and mean values of temperature and relative humidity of the air in the laboratories are presented in Table 3. The comparison of the studied rooms in relation to these physical parameters showed statistically significant differences for the air temperature measurements only (ANOVA: $p<0.01$ ). The major differences were noted between the workplaces and the outdoor background (Scheffe's test: $\mathrm{p}<0.01$ ), although in either case did not significantly affect the concentration of microorganisms. In the case of the relative humidity of the air, correlation analysis showed its statistically significant effect only on the concentration of microorganisms measured using an Andersen impactor at workplaces. Presumably, the humidity which affected the hydration of microbial agar media used as collection surfaces during aspiration of biological particles from the air, played a key role here. The higher the humidity of a medium, the lower the stress connected with viability of microorganisms actively separated from the air and deposited on individual stages of a sampler. The positive correlation coefficient values support this statement with respect to concentrations of viable microorganisms $\left(\mathrm{r}^{2}=0.48, \mathrm{p}<0.05\right)$, especially bacteria $\left(r^{2}=0.55, p<0.05\right)$. Regarding the concentrations of both bacteria and fungi found in the settled dust deposited on the conserved objects, none of the microclimatic parameters of the air had statistically significant effects on them.

\section{DISCUSSION}

Concentration of bacterial and fungal aerosols measured using an Andersen impactor in indoor (at workplaces in conservation laboratories as well as in the background) and outdoor air did not exceed the value of $2000 \mathrm{cfu} / \mathrm{m}^{3}$ in any segment of the studied environment. To the best of our knowledge, there is no report in the peer-reviewed scientific literature on bioaerosol contamination of cultural heritage conservation laboratories. Hence, the results of this study can only be compared with the data obtained in libraries or archive storerooms.

The scientific evidence obtained heretofore regarding bioaerosol contamination revealed in the above locations a similar range of concentrations (i.e., $10^{1}-10^{3} \mathrm{cfu} / \mathrm{m}^{3}$ ) [6,25-29]. As to the total microbial counts measured in libraries, the only data available are those published

Table 3. Temperature and relative humidity at workplaces in conservation laboratories and in indoor and outdoor backgrounds

\begin{tabular}{|c|c|c|c|c|}
\hline \multirow[t]{2}{*}{ Sampling place } & \multicolumn{2}{|c|}{$\begin{array}{c}\text { Temperature } \\
{\left[{ }^{\circ} \mathrm{C}\right]} \\
\end{array}$} & \multicolumn{2}{|c|}{$\begin{array}{c}\text { Relative humidity } \\
{[\%]}\end{array}$} \\
\hline & $\mathrm{M}$ & $\min .-\max$ & $\mathrm{M}$ & $\min .-\max$ \\
\hline Workplaces & 23 & $22-24$ & 43 & $32-56$ \\
\hline Indoor background & 21 & $19-23$ & 41 & $31-55$ \\
\hline Outdoor background & 17 & $13-22$ & 47 & $30-59$ \\
\hline
\end{tabular}

Abbreviations as in Table 1. 
by Wlazło et al. [26] and Harkawy et al. [9]. The authors found that total microbial concentrations in library interiors were between $10^{4}-10^{5}$ counts $/ \mathrm{m}^{3}$, i.e., within the same range as in the case of cultural heritage conservation laboratories. Besides, the comparison of culturable bioaerosol concentrations with total microbial counts revealed that the numbers of viable particles were significantly lower than their total counts for both personal and stationary sampling locations. The noted proportion is in a good agreement with the observations made by Hýsek et al. [30] and Wlazło et al. [26].

So far, no global, universally binding values of admissible concentrations of microbial contaminations at work environment have been established. Such proposals, if made at all, have the nature of national or industrial recommendations only [31,32], and do not relate to the work environment connected with conservation of works of art. Today, in hygienic control of the work environment, determination of the degree of microbial air contamination, reflected by the number of colony forming units in $1 \mathrm{~m}^{3}$ of the air, is the best known and most frequently used measure of exposure [32].

In the presented study, for quantitative interpretation of the results, the classification of threshold limit values (TLV) for airborne microorganisms in public utility facilities proposed by the Expert Group on Biological Agents at the Polish Interdepartmental Commission for Maximum Admissible Concentrations and Intensities for Agents Harmful to Health in the Working Environment was used [32]. These values $\left(5 \times 10^{3} \mathrm{cfu} / \mathrm{m}^{3}\right.$ for both bacteria and fungi) were developed as a result of volumetric measurements of environmental bioaerosols, allowing for the potential harmfulness of a given biological agent, and they should be treated as a facultative standard or auxiliary reference values. Based on the TLVs proposed by the Expert Group, it can be concluded that the concentration of both the bacteria and fungi in the studied interiors did not exceed the admissible values.
In the literature on the subject, one can find a number of proposed reference values regarding the environments from where museum objects can be moved to a conservation laboratory, i.e., museums, libraries or archives. In these cases, however, what is taken into account are not the harmful effects of microbial agents on humans, but on objects housed in a given facility. Therefore, the Ministero dei Beni e delle Attività Culturali e del turismo (MIBAC) [33] proposed the following threshold values of risk: the concentrations of heterotrophic bacteria should be $<750 \mathrm{cfu} / \mathrm{m}^{3}$, and fungi $<150 \mathrm{cfu} / \mathrm{m}^{3}$. Flieder and Capderou [34] as well as Parchas [35] suggest that the fungal aerosol concentration should not exceed $100-120 \mathrm{cfu} / \mathrm{m}^{3}$ or the collections should be subjected to disinfection. Cieplik [25] established the TLV depending on the species composition of bioaerosols and assumed that the maximum concentration should not exceed $150 \mathrm{cfu} / \mathrm{m}^{3}$ if the bioaerosol is a mixture of several fungal species or $50 \mathrm{cfu} / \mathrm{m}^{3}$ for a particular species. At the same time, the author allowed the concentration of $500 \mathrm{cfu} / \mathrm{m}^{3}$ if the fungi belong to typical microbial genera present in the atmospheric air, such as Cladosporium and Alternaria.

Piotrowska et al. [36] and Karbowska-Berent et al. [29] suggested the level of $200 \mathrm{cfu} / \mathrm{m}^{3}$ as a limit value, concluding that the higher concentrations of fungi in the air of libraries or archives can signal the existence of a moisture problem or presence of internal microbial sources. According to Brokerhof et al. [37], if fungal concentrations in archives range $0-25 \mathrm{cfu} / \mathrm{m}^{3}$, no problems should be expected; if the range is $25-100 \mathrm{cfu} / \mathrm{m}^{3}$, the presence of an emission source is likely; if they vary $100-1000 \mathrm{cfu} / \mathrm{m}^{3}$, an indoor source exists; and if molds are often observed on objects $>1000 \mathrm{cfu} / \mathrm{m}^{3}$, an active growth is present indoors. These numerical values apply to the mixed fungal strains. If there is only 1 species found, then quantities of 25$100 \mathrm{cfu} / \mathrm{m}^{3}$ already indicate the presence of the infection of the stored objects. 
Taking into account both the maximum bacterial $\left(1845 \mathrm{cfu} / \mathrm{m}^{3}\right)$ and fungal $\left(413 \mathrm{cfu} / \mathrm{m}^{3}\right)$ concentrations registered in the studied cultural heritage conservation laboratories and their qualitative composition, it seems reasonable to conclude that all the measured values were higher than the TLVs suggested by the authors quoted above. This fact should be regarded as a warning signal for indoor air quality improvement against possible biodeterioration of the conserved objects. The hermetization of this type of working environment through its mechanical isolation from an inflow of outdoor contaminants (e.g., an augmentation of air-tightness or an introduction of air-conditioning system, etc.) could be a good solution for solving the majority of these hygienic quality problems. The results of the presented study showed that human activity at workplaces where conservation works on microbiologically contaminated museum objects were carried out, had a significant effect on the concentrations of both bacterial and fungal aerosols. Nevertheless, in the case of fungi, the main process which leads to contamination of the studied rooms was infiltration of ambient air, accompanied by the migration of fungal spores from outdoors to the studied interiors. The indoor/outdoor ratio $(\mathrm{I} / \mathrm{O})$ calculated from the concentrations determined using an Andersen impactor for bacterial (1.4) and fungal (0.4) aerosols supports the above conclusion.

This finding was also confirmed by the results of qualitative analysis (i.e., most species of fungi identified in the ambient air were also isolated from the indoor air in conservation laboratories) (Table 2), and the correlation analysis between the concentrations of microorganisms in the air and settled dust (which did not reveal a statistical significance showing that settled dust was not the only source of microbial contamination at studied workplaces). In a number of proposed hygienic standards regarding the indoor environment, the ratio of concentrations concurrently measured inside and outside a studied facility is utilized to determine admissible contamination with simultaneous identification of its main source [32]. The indoor/outdor ratio below $1(\mathrm{I} / \mathrm{O}<1)$ is usually interpreted as no contamination inside a given facility, or as a level of acceptable contamination. Thus, in accordance with the AIHA proposal [38], a high value of the I/O indicates the presence of an internal source of emission of microbial agents. According to the American Conference of Governmental Industrial Hygienists (ACGIH) proposals, [39], a value of the $\mathrm{I} / \mathrm{O}<1$ indicates no indoor contamination if the qualitative composition of microbiota in the indoor and outdoor air does not differ.

According to Burge [40], if the bioaerosol in the studied rooms differs in terms of quality from the outdoor air, and if its concentration is higher than $1.0 \times 10^{3} \mathrm{cfu} / \mathrm{m}^{3}$, and persistently exceeds at least two-fold the concentration found indoors, it is necessary to undertake preventive measures in terms of indoor hygiene. According to Reponen et al. [41], if the $\mathrm{I} / \mathrm{O}$ is $>1$ (in summer), it confirms the presence of an internal source of microorganism emission. According to Reynolds et al. [42], if there is a significant difference between bioaerosol concentration inside and outside the studied room ( $\mathrm{I} / \mathrm{O}$ ratio is much bigger than 1 ), an internal source of microbial emission is present.

Pursuant to Portuguese legislation [43], total indoor concentration of fungi should be lower than that found outdoors, and the presence of certain species, i.e., Stachybotrys chartarum, Fusarium spp., Aspergillus versicolor, A. flavus, A. fumigatus, A. niger, Histoplasma capsulatum and Cryptococcus neoformans, should be considered dangerous.

In the light of the above, the results of this study showed that the microbial contamination in conservation laboratories was not excessive as far as concentrations of airborne microorganisms are concerned, although the presence of Stachybotrys chartarum, Fusarium spp., Aspergillus flavus, A. fumigatus and A. niger species (Table 2) in the air and settled dust indicates a significant health hazard in the studied environment. 
There are also several guidelines which address health risk issues based on indoor viable fungal concentrations in the air, as well as on surfaces. One of the latest examples is the Australian Mould Guideline, which proposes airborne and surface fungal contamination rating guide [44].

According to the fungal concentrations measured in conservation laboratories in that study, the health risk can be: - "elevated" (i.e., may present a health risk to sensitized individuals; health symptoms should be noted) in terms of the level of viable fungi in the air when the average concentration value is considered, but

- "at risk" (potential health risk to sensitized individuals; health symptoms should be monitored and assessed by a physician where required) if several maximum concentrations are taken into account;

- "normal" in terms of the level of viable fungi on the surfaces when the average concentration value is considered, but

- "elevated" (i.e., the surface will require cleaning to remove molds; if porous, may need removal) when several maximum concentrations are considered.

Recently, several Italian authors proposed an integrated approach to the study of biological pollution in indoor environments such as libraries and archives. This approach includes microbial air and surface sampling, complemented by an investigation of allergens and pollens [45]. The results obtained in the presented study in cultural heritage conservation laboratories suggest that for recognition of potential health risk to exposed workers, a precise assessment of contamination level containing a control of both viable (culturable) and total particle counts is a minimum requirement.

The study in conservation laboratories showed that quantitative assessment of viable bioaerosol can be made using both impactor and filter samplers, irrespective of whether they are used for stationary or personal sampling. Moreover, in this type of indoor environment, both tested filter samplers can be interchangeably applied to control microbial contamination of the air, regardless of the stationary or personal sampling strategy as well as viability (culturability) of microbial particles.

As mentioned earlier, the concentrations obtained by stationary measurements using Button and GSP samplers were always lower than the corresponding values obtained by personal control; however, these differences were statistically significant for Button sampler measurements only. The observed relationship is probably due to the way in which both samplers capture the particles. While both of them collect particles with an aerodynamic diameter of up to $5 \mu \mathrm{m}$, with high, over $90 \%$ efficiency, in the case of the Button sampler, due to special screen construction, collection of particles is independent of the direction of a particle-carrying air stream inflow. Thus, the worker's posture assumed at work does not reduce particles' ability to deposit on a filter $[11,46]$.

Qualitative evaluation of the air in conservation laboratories showed that the results of taxonomic analysis of microbiota in this type of interiors are in close relationship with both the type of sampler used and the measurement strategy applied. The largest number of groups of microorganisms was identified using an Andersen impactor (as mentioned, 99 species of microorganisms in total - 42 bacteria and 57 fungi). Compared with the impactor, the GSP and Button samplers showed lower sensitivity in detecting individual microbial groups (using these instruments, a total of 36 microorganisms were isolated from the air, 18 species of bacteria and 18 of fungi - Table 2). The lower numbers of microbial taxa identified from GSP and Button samplers were probably due to biological stress during both the sampling process (desiccation) and analytical processing of the samples (filter dissolution). However, it should be emphasized that the presence of 3 mold species (Penicillium griseoazureum, P. griseofulvum and P. verrucosum) in the air was confirmed through the use of the filtration technique only, and had not been detected using an Andersen impactor. 
Moreover, it should be noted that for measurements with an Andersen impactor, MEA was used as the universal medium for fungal particle collection. As the latest Finnish study has shown [47], the use of various microbial media (e.g., DG18 or MEA) in this device for quantitative evaluation of fungal aerosol particles does not have a statistically significant effect on the results of their concentration measurements. However, in the case of qualitative evaluation of this type of samples, it has been shown that the DG18 medium makes the isolation of xerophilic organisms, especially from the Aspergillus (e.g., A. restrictus), Wallemia and Eurotium genera, significantly easier. Thus, the actual count of these microorganisms in the air in conservation laboratories could have probably been higher than that one found in the presented study.

As mentioned, taking into account the physical dimensions of predominant bacteria and fungi, the size distribution allows defining the forms in which these particles are present in the air. Moreover, the particle sizes, shapes, densities, chemical composition and reactivity determine how deep, i.e., which level of the respiratory tract, they will reach and how they will behave. Apart from the enumerated parameters, the mechanism of particle deposition is affected also by the rate of airflow, manner of breathing and pulmonary ventilation, which depends on the age and activity dynamics [48-50].

As studies show, particles smaller than $2.5 \mu \mathrm{m}$ (actinomycetal pseudoconidia, the majority of spores of filamentous fungi occurring in indoor environments) pose the greatest hazard to the health of persons exposed through inhalation. As they are able to overcome numerous defense systems in the respiratory tract (e.g., epithelial cilia, mucus, saliva, etc.), they can relatively deeply deliver substantial quantities of substances which can cause damage at the cell level [51]. Interaction between aerosol particles and body cells, to a major degree, is dependent on where they deposit. Particles smaller than $5 \mu \mathrm{m}$ (most fungal and actinomycetal spore and mycelium particles) can penetrate into the lower respiratory tract where the reactions tend to manifest as allergic inflammation $[52,53]$.

Analysis of size distribution of bioaerosols at the studied workplaces showed that the predominant groups (with the highest percentage share in total) of microorganisms, i.e., Gram-positive cocci and filamentous fungi, occurred: bacteria in the form of single cells and small aggregates of bacteria and/or bacteria and dust (i.e., 1.1$4.7 \mu \mathrm{m}$ ); fungi in the form of single spores (i.e., 1.1$4.7 \mu \mathrm{m})$, respectively. Hence, the largest "load" of microorganisms can penetrate into the human respiratory tract between the trachea and terminal bronchi. Thus, adverse health effects connected with immunological reactivity of these particles can manifest as allergic inflammatory reactions in exposed workers [54-56]. This type of influence has usually been observed among workers (including art conservators) in museums, libraries and archives [7,57,58].

Kolmodin-Hedman et al. [59], while studying exposure to molds among museum workers, found cases of toxic syndrome caused by exposure to organic dust containing the Aspergillus versicolor and Penicillium verrucosum species. Wiszniewska et al. [58,60], assessing the prevalence of allergic diseases among art conservators, found that $85 \%$ of workers reported allergic symptoms and $34.5 \%$ of them linked intensification of symptoms with workplace exposure to exhibits contaminated with filamentous fungi. In the same percentage of art conservators, the results of skin prick tests using mold allergens were positive. Usually, there is no statistically significant correlation between such a high incidence of allergic symptoms and the level of viable microorganisms identified in the work environment [61-63]. For example, Roussel et al. [64] showed that people working in contaminated archives did not report more allergy symptoms than others; however, their contact with moldy documents resulted in a higher prevalence of headaches, fatigue, eye and throat irritation, as well as rhinorrhea. 
The results of tests conducted in this study suggest that low correlation between epidemiologically confirmed appearance of adverse health outcomes and the concentration of harmful microbial agents can be caused by the fact that only the concentrations of viable bioaerosol particles are considered. As shown at workplaces in conservation laboratories, viable microbial particles accounted for as little as $0.1-5.5 \%$ of total bioaerosol. Thus, this is the proportion of the underestimated numbers of particles which, with respect to their immunological reactivity, retain all of their characteristics vital from the perspective of health effects.

\section{CONCLUSIONS}

Microbial contaminations at workplaces in cultural heritage conservation laboratories assessed from the concentrations of viable microorganisms in the air were low (i.e., $<2000 \mathrm{cfu} / \mathrm{m}^{3}$ ) and did not exceed the threshold limit values proposed for public utility facilities. Nevertheless, the concentration of viable bioaerosol particles in the studied interiors accounted for not more than $5.5 \%$ of total microorganism concentration. It explicitly shows that evaluating microbiological purity in the work environment of art conservators, based solely on the measurements of viable microbial components of the air, leads to significant underestimation of the actual exposure.

The presented study shows that staff activity at workplaces substantially affects their contamination level, both with bacterial and fungal particles. In the case of fungi, however, the main process which leads to workplace contamination was infiltration of ambient air and the following migration of their spores into the studied rooms. A vital element of interior contamination was the very objects which underwent conservation works as well. Gram-positive cocci, non-sporing Gram-positive rods and filamentous fungi were predominant in the air at workplaces in the studied laboratories; among them, cellulolytic, lipolytic and proteolytic organisms were identified.
The microbial composition of settled dust was less diverse than that of the airborne dust but contained analogous species. Using the classification of biological agents specified in Directive 2000/54/EC [23], it was ascertained that in the working environment of art conservators, the presence of the identified microorganisms might serve as an evidence of a significant source of health hazard.

With respect to the methodology, the presented study shows that quantitative assessment of viable bioaerosol in conservation laboratories can be done using both impactor and filter samplers, irrespective of whether they are used for personal or stationary measurements. Furthermore, analyses of viable and total bioaerosols showed that both Button and GSP filter samplers were equally efficient for collecting microbial particles, and could be interchangeably used for the assessment of this type of pollution. Nevertheless, it should be pointed out that the use of filter samplers solely for the monitoring of microbial contamination substantially limits the scope of qualitative information which can be obtained.

It has been demonstrated that the number of species identified using these instruments was significantly different from those identified using an impactor (18 species of bacteria and 18 species of fungi vs. 42 species of bacteria and 57 species of fungi). Moreover, the use of a 6-stage Andersen impactor allowed obtaining data about size distribution of the airborne microorganisms, and based on that, defining their form and determining the depth of possible penetration into the respiratory tract of exposed workers. As seen in the analyses, art conservators are exposed to bacteria which occur mainly as single cells or in the form of small aggregates and to filamentous fungi occurring as single spores. Thus, the largest "load" of microorganisms can penetrate into the respiratory tract between the trachea and terminal bronchi, and adverse health effects connected with immunological reactivity of the studied bioaerosol particles can chiefly cause allergic inflammatory reactions. 
The results also clearly suggest that for evaluation of potential health risk of workers exposed to microbial hazards, a precise assessment of their contamination level, including information on, both viable (culturable) and total particle counts, is a minimum requirement. Moreover, a hermetization of this type of working environment through its mechanical isolation from an inflow of outdoor contaminants, introduction of glove boxes or local exhaust ventilation benches, and the control of microclimate parameters of the incoming air (especially relative humidity) should be implemented to assure proper hygienic quality.

\section{REFERENCES}

1. United Nations Educational, Scientific and Cultural Organization. Convention Concerning the Protection of the World Cultural and Natural Heritage. General Conference at its seventeenth session. Paris: The Organization; 1972.

2. Dutkiewicz J, Górny RL. [Biological factors hazardous to human health: Classification and criteria of exposure assessment]. Med Pr. 2002;53(1):29-39. Polish.

3. Utell M, Samet J. Airborne particles and respiratory disease: Clinical and pathogenetic considerations. In: Wilson R, Spengler JD, editors. Particles in our air: Concentrations and health effects. Cambridge: Harvard University Press; 1996. p. 169-88.

4. Gallo F. Aerobiological research and problems in libraries. Aerobiologia. 1993;9:117-30, http://dx.doi.org/10.1007/ BF02066253.

5. Ciferri O, Tiano P, Mastromei G. Of microbes and art. The role of microbial communities in the degradation and protection of cultural heritage. Dordrecht: Kluwer Academic Publishers; 2000.

6. Borrego S, Guiamet P, Gomez de Saravia S, Batistini P, Garcia M, Lavin P, et al. The quality of air at archives and the biodeterioration of photographs. Int Biodeterior Biodegradation. 2010;64:139-45, http://dx.doi.org/10.1016/j.ibiod. 2009.12.005.
7. Zielińska-Jankiewicz K, Kozajda A, Piotrowska M, Szadkowska-Stańczyk I. Microbiological contamination with moulds in work environment in libraries and archive storage facilities. Ann Agric Environ Med. 2008;15(1):71-8.

8. Engelhart S, Exner M. Short-term versus long-term filter cassette sampling for viable fungi in indoor air: Comparative performance of the Sartorius MD8 and the GSP sampler. Int J Hyg Environ Health. 2002;205:443-51, http://dx.doi. org/10.1078/1438-4639-00183.

9. Harkawy A, Górny RL, Ogierman L, Wlazło A, ŁawniczekWałczyk A, Niesler A. Bioaerosol assessment in naturally ventilated historical library building with restricted personnel access. Ann Agric Environ Med. 2011; 18(2):323-9.

10. Adhikari A, Martuzevicius D, Reponen T, Grinshpun SA, Cho S-H, Sivasubramani SK, et al. Performance of the Button Personal Inhalable Sampler for the measurement of outdoor aeroallergens. Atmos Environ. 2003;37:4723-33, http:// dx.doi.org/10.1016/j.atmosenv.2003.08.021.

11. Lee T, Grinshpun SA, Martuzevicius D, Adhikari A, Crawford CM, Luo J, et al. Relationship between indoor and outdoor bioaerosols collected with a Button inhalable aerosol sampler in urban homes. Indoor Air. 2006;16:37-47, http:// dx.doi.org/10.1111/j.1600-0668.2005.00396.x.

12. Yao M, Mainelis G. Effect of physical and biological parameters on enumeration of bioaerosols by portable microbial impactors. J Aerosol Sci. 2006;37:1467-83, http://dx.doi. org/10.1016/j.jaerosci.2006.06.005.

13. Huttunen K, Rintala H, Hirvonen M-R, Vepsalainen A, Hyvarinen A, Meklin T, et al. Indoor air particles and bioaerosols before and after renovation of moisture-damaged buildings: The effect on biological activity and microbial flora. Environ Res. 2008;107:291-8, http://dx.doi.org/10.1016/ j.envres.2008.02.008.

14. Gołofit-Szymczak M, Górny RL. Bacterial and fungal aerosols in air-conditioned office buildings in Warsaw, Poland - Preliminary results (winter season). Int J Occup Saf Ergon. 2010;16(4):407-18. 
15. Palmgren U, Strom G, Blomquist G, Malmberg P. Collection of airborne microorganisms on nucleopore filters: Estimation and analysis - CAMNEA method. J Appl Bacteriol.1989;61:401-6,http://dx.doi.org/10.1111/j.1365-2672.1986. tb04303.x.

16. Wang Z, Reponen T, Grinshpun SA, Górny RL, Willeke K. Effect of sampling time and air humidity on the bioefficiency of filter samplers for bioaerosol collection. J Aerosol Sci. 2001;32:661-74, http://dx.doi.org/10.1016/S00218502(00)00108-7.

17. Murray PR, Rosenthal KS, Pfaller MA. Medical microbiology. 7th ed. Philadelphia: Elsevier Saunders; 2013.

18. Litwinow MA. [Guide to soil microscopic fungi]. Leningrad: Izdatielstwo Nauka; 1967. Russian.

19. Domsch KH, Gams W, Anderson TH. Compendium of soil fungi. Eching: IHV Verlag; 1993.

20. St-Germain G, Summerbell R. Identifying filamentous fungi. 2nd ed. Belmont: Star Publishing Company; 2011.

21. Klich MA. Identification of common Aspergillus species. Utrecht: Centraalbureau voor Schimmelcultures; 2002.

22. Samson RA, Hoekstra ES, Frisvad JC. Introduction to foodand airborne fungi. 7th ed. Utrecht: Centraalbureau voor Schimmelcultures; 2004.

23. Directive 2000/54/EC of the European Parliament and of the Council of 18 September 2000 on the protection of workers from risks related to exposure to biological agents at work. Off J Eur Union L 262/21, p. 21-45 (Oct 17, 2000).

24. [Ordinance of the Minister of Health of April 22, 2005, on hazardous biological agents in the work environment and the protection of health of workers occupationally exposed to them. J Laws 2005, No. 81, item 716]. Polish.

25. Cieplik Z. [Mold contamination of Polish studies library at Faculty of Philology, Silesian University]. Stud Bibliol. 1997;10:107-19. Polish.

26. Wlazło A, Górny RL, Złotkowska R, Ławniczek A, ŁudzeńIzbińska B, Harkawy A, et al. [Workers' exposure to selected biological agents in libraries of Upper Silesia]. Med Pr. 2008;59:159-70. Polish.
27. Niesler A, Górny RL, Wlazło A, Łudzeń-Izbińska B, Ławniczek-Wałczyk A, Gołofit-Szymczak M, et al. Microbial contamination of storerooms at the Auschwitz-Birkenau Museum. Aerobiologia. 2010;26:125-33, http://dx.doi. org/10.1007/s10453-009-9149-z.

28. Guiamet P, Borrego S, Lavin P, Perdomo I, Gomez de Saravia $S$. Biofouling and biodeterioration in materials stored at the Historical Archive of the Museum of La Plata, Argentine and at the National Archive of the Republic of Cuba. Colloids Surf B Biointerfaces. 2011;85:229-34, http://dx.doi. org/10.1016/j.colsurfb.2011.02.031.

29. Karbowska-Berent J, Górny RL, Strzelczyk AB, Wlazło A. Airborne and dust borne microorganisms in selected Polish libraries and archives. Build Environ. 2011;46(10):1872-9, http://dx.doi.org/10.1016/j.buildenv.2011.03.007.

30. Hysek J, Fisar Z, Zizka Z, Kofronova O, Binek B. Airborne microorganism monitoring: A comparison of several methods, including a new direct counting technique. Zentralbl Mikrobiol. 1991;146:435-43.

31. Cappitelli F, Pasquariello G, Tarsitani G, Sorlini C. Scripta manent? Assessing microbial risk to paper heritage. Trends Microbiol. 2010;18:538-42, http://dx.doi.org/10.1016/j.tim. 2010.09.004.

32. Górny RL, Cyprowski M, Ławniczek-Wałczyk A, GołofitSzymczak M, Zapór L. Biohazards in the indoor environment - A role for threshold limit values in exposure assessment. In: Dudzińska MR, editor. Management of indoor air quality. Leiden: CRC Press/Balkema; 2011. p. 1-20, http:// dx.doi.org/10.1201/b11336-2.

33. [MIBAC - the Italian Ministry of Cultural Heritage. Official guidelines on technical-scientific criteria and standards of operation and development of museums. Scope VI]. J Laws 1998, No. 150, item 6]. Italian.

34. Flieder F, Capderou C. [Safeguarding of heritage collections: The lute against biological deteriorations]. Paris: CNRS Editions; 1999. French.

35. Parchas M-D. [How to deal with biohazards?]. Paris: Direction des Archives de France; 2008. French. 
36. Piotrowska M, Zielińska-Jankiewicz K, Kozajda A, Gutarowska B. [Air contamination by filamentous fungi in archives and libraries]. Ochr Koroz. 2006;9:176-96. Polish.

37. Brokerhof A, van Zanen S, den Teuling A. Fluffy staff. Integrated control of mould in archives. Amsterdam: Institute for Cultural Heritage; 2007. p. 26-7.

38. American Industrial Hygiene Association. The practitioner's approach to IAQ investigations. In: Weekes DM, Gammage RB, editors. Proceedings of the Indoor Air Quality International Symposium; 1989 May 23; St. Louis, USA. Fairfax: The Association; 1989. p. 43, 66.

39. American Conference of Governmental Industrial Hygienists. Guidelines for assessment of bioaerosols in indoor environment. Cincinnati: The Conference; 1989.

40. Burge HA. Bioaerosols: Prevalence and health effects in the indoor environment. J Allergy Clin Immunol. 1990;86: 687-701, http://dx.doi.org/10.1016/S0091-6749(05)80170-8.

41. Reponen T, Nevalainen A, Jantunen M, Pellikka M, Kalliokoski P. Proposal for an upper limit of the normal range of indoor air bacterial and fungal spores in subarctic climate. In: Walkinshaw DS, editor. Indoor Air ' 90 . Procedings of the 5th International Conference on Indoor Air Quality and Climate; 1990 Jul 29 - Aug 3; Toronto, Canada. Vol. 2. Ottawa: Canada Mortgage and Housing Corporation; 1990. p. 47-50.

42. [Energy certification for indoor air - Technical standard NTSCE-02: Methodology for periodic audits of IAQ in existing buildings in the scope of RSECE. J Laws 2006, No. 79]. Portuguese.

43. Reynolds SJ, Streifel AJ, McJilton CE. Elevated airborne concentrations of fungi in residential and office environments. Am Ind Hyg Assoc J. 1990;51:601-4, http://dx.doi. org/10.1080/15298669091370185.

44. Kemp P, Neumeister-Kemp H. Australian mould guideline. Osborne Park: The Enviro Trust; 2010.

45. Pasquarella C, Saccani E, Sansebastiano GE, Ugolotti M, Pasquariello G, Albertini R. Proposal for a biological environmental monitoring approach to be used in libraries and archives. Ann Agric Environ Med. 2012;19(2):209-12.
46. Aizenberg V, Grinshpun SA, Willeke K, Smith J, Baron PA. Performance characteristics of the Button personal inhalable aerosol sampler. Am Ind Hyg Assoc J. 2000;61:398404, http://dx.doi.org/10.1080/15298660008984550.

47. Hakkila S. Dichloran glycerol agar (DG18) in indoor air mould sampling. Allergol Immunol. 2012;9:178.

48. Phalen RF, Oldham MJ. Methods for modelling particle deposition as a function of age. Respir Physiol. 2001;128:11930, http://dx.doi.org/10.1016/S0034-5687(01)00270-5.

49. Owen MK, Ensor DS, Sparks LE. Airborne particle sizes and sources found in indoor air. Atmos Environ. 1992;26:214962, http://dx.doi.org/10.1016/0960-1686(92)90403-8.

50. Reponen T, Grinshpun SA, Conwell KL, Wiest J, Anderson M. Aerodynamic versus physical size of spores: Measurement and implication on respiratory deposition. Grana. 2001;40:119-25, http://dx.doi.org/10.1080/00173130 152625851.

51. Spengler J, Wilson R. Emission, dispersion, and concentration of particles. In: Wilson R, Spengler JD, editors. Particles in our air: Concentrations and health effects. Cambridge: Harvard University Press; 1996. p. 41-62.

52. Reponen T. Viable fungal spores as indoor aerosols [Ph.D. thesis]. Kuopio: University of Kuopio; 1994.

53. Horner WE, Helbling A, Salvaggio JE, Lehrer SB. Fungal allergens. Clin Microbiol Rev. 1995;8:161-79.

54. Gambale W, Croce J, Costa-Manso E, Croce M, Sales M. Library fungi at the University of Sao Paulo and their relationship with respiratory allergy. J Investig Allergol Clin Immunol. 1993;3:45-50.

55. Lacey J, Dutkiewicz J. Bioaerosols and occupational lung disease. J Aerosol Sci. 1994;25:1371-404, http://dx.doi. org/10.1016/0021-8502(94)90215-1.

56. Flannigan B, Samson RA, Miller JD. Microorganisms in home and indoor work environments: Diversity, health impacts, investigation and control. Boca Raton: CRC Press; 2011, http://dx.doi.org/10.1201/b10838.

57. Karbowska-Berent J, Jarosińska D, Muszyńska-Graca M. [Evaluation of allergy and mycosis risk in the work 
environment of library and archival staff]. Notes Konserw. 2007;11:255-66. Polish.

58. Wiszniewska M, Walusiak-Skorupa J, Pannenko I, Draniak M, Pałczyński C. Occupational exposure and sensitization to fungi among museum workers. Occup Med. 2009; 59:237-42, http://dx.doi.org/10.1093/occmed/kqp043.

59. Kolmodin-Hedman B, Blomquist G, Sikstrom E. Mould exposure in museum personnel. Int Arch Occup Environ Health. 1986;57:321-3, http://dx.doi.org/10.1007/BF0 0406187.

60. Wiszniewska M, Świerczyńska-Machura D, Pałczyński C, Walusiak-Skorupa J. [Fungal allergy among art conservators: Prevalence, risk factors and clinical symptoms]. Med Pr. 2010;61:133-41. Polish.

61. Platt SD, Martin CJ, Hunt SM, Lewis CW. Damp housing, mold growth, and symptomatic health state. BMJ. 1989;298:1673-8, http://dx.doi.org/10.1136/bmj.298. 6689.1673.

62. Waegemaekers M, van Wageningen N, Brunekreef B, Boleij JSM. Respiratory symptoms in damp houses. Allergy. 1989;44:192-8, http://dx.doi.org/10.1111/j.1398-9995. 1989.tb02261.x.

63. Hyvarinen A, Toivola M, Halla-aho J, Husman T, Kauhanen E, Koivisto J, et al. Childhood asthma and residential moisture damages. In: Raw G, Aizlewood C, Warnen P, editors. Proceedings of Indoor Air '99, The 8th International Conference on Indoor Air Quality and Climate; 1999 Aug 8-13; Edinburgh, Scotland. Vol. 5. London: Construction Research Communications Ltd.; 1999. p. 451-2.

64. Roussel S, Reboux G, Millon L, Parchas M-D, Boudih S, Skana F, et al. Microbiological evaluation of 10 French archives and link to occupational symptoms. Indoor Air. 2012;22: 514-22, http://dx.doi.org/10.1111/j.1600-0668.2012.00781.x.

65. Urzi C, de Leo F. Biodeterioration of cultural heritage in Italy: State of art. Proceedings of ARIADNE 8 Workshop; 2001 Dec 10-15; Prague, Czech Republic. Prague: Academy of Sciences of the Czech Republic; 2001.

66. Strzelczyk AB, Karbowska-Berent J. [Microorganisms and insects as relic deteriogens and their control]. Toruń: Wydawnictwo Uniwersytetu im. M. Kopernika; 2004. Polish.

67. Zyska B. Fungi isolated from library materials: A review of the literature. Int Biodeterior Biodegradation. 1997;40:4351, http://dx.doi.org/10.1016/S0964-8305(97)00061-9.

68. Lugauskas A, Krikstaponis A. Microscopic fungi found in the libraries of Vilnius and factors affecting their development. Indoor Built Environ. 2004;13:169-82, http://dx.doi. org/10.1177/1420326X04045274.

69. Sterflinger K. Fungi: Their role in deterioration of cultural heritage. Fungal Biol Rev. 2010;24:47-55, http://dx.doi. org/10.1016/j.fbr.2010.03.003.

This work is available in Open Access model and licensed under a Creative Commons Attribution-NonCommercial 3.0 Poland License - http://creativecommons.org/ licenses/by-nc/3.0/pl/deed.en. 